\title{
Nutrient-stimulated insulin secretion in mouse islets is critically dependent on intracellular $\mathrm{pH}$ Subhadra C Gunawardana, Jonathan V Rocheleau, W Steven Head and David W Piston*
}

Address: Department of Molecular Physiology and Biophysics, 702 Light Hall, Vanderbilt University, Nashville, TN 37232, USA

Email: Subhadra C Gunawardana - subhadra.gunawardana@Vanderbilt.Edu; Jonathan V Rocheleau - Jon.Rocheleau@Vanderbilt.Edu; W Steven Head - steven.head@Vanderbilt.Edu; David W Piston* - dave.piston@Vanderbilt.Edu

* Corresponding author

Published: II June 2004

BMC Endocrine Disorders 2004, 4:I
Received: 09 February 2004

Accepted: II June 2004

This article is available from: http://www.biomedcentral.com/I472-6823/4/I

(c) 2004 Gunawardana et al; licensee BioMed Central Ltd. This is an Open Access article: verbatim copying and redistribution of this article are permitted in all media for any purpose, provided this notice is preserved along with the article's original URL.

\begin{abstract}
Background: Many mechanistic steps underlying nutrient-stimulated insulin secretion (NSIS) are poorly understood. The influence of intracellular $\mathrm{pH}\left(\mathrm{pH}_{\mathrm{i}}\right)$ on insulin secretion is widely documented, and can be used as an investigative tool. This study demonstrates previously unknown effects of $\mathrm{pH}_{\mathrm{i}}$-alteration on insulin secretion in mouse islets, which may be utilized to correct defects in insulin secretion.
\end{abstract}

Methods: Different components of insulin secretion in mouse islets were monitored in the presence and absence of forced changes in $\mathrm{pH}_{\mathrm{i}}$. The parameters measured included timedependent potentiation of insulin secretion by glucose, and direct insulin secretion by different mitochondrial and non-mitochondrial secretagogues. Islet $\mathrm{pH}_{\mathrm{i}}$ was altered using amiloride, removal

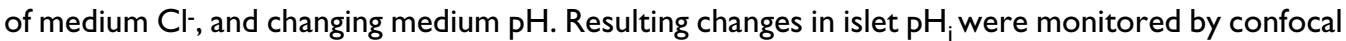
microscopy using a $\mathrm{pH}$-sensitive fluorescent indicator. To investigate the underlying mechanisms of the effects of $\mathrm{pH}_{\mathrm{i}}$-alteration, cellular $\mathrm{NAD}(\mathrm{P}) \mathrm{H}$ levels were measured using two-photon excitation microscopy (TPEM). Data were analyzed using Student's $t$ test.

Results: Time-dependent potentiation, a function normally absent in mouse islets, can be unmasked by a forced decrease in $\mathrm{pH}_{\mathrm{i}}$. The optimal range of $\mathrm{pH}_{\mathrm{i}}$ for $\mathrm{NSIS}$ is 6.4-6.8. Bringing islet $\mathrm{PH}_{\mathrm{i}}$ to this range enhances insulin secretion by all mitochondrial fuels tested, reverses the inhibition of glucose-stimulated insulin secretion (GSIS) by mitochondrial inhibitors, and is associated with increased levels of cellular $\mathrm{NAD}(\mathrm{P}) \mathrm{H}$.

Conclusions: Pharmacological alteration of $\mathrm{pH}_{\mathrm{i}}$ is a potential means to correct the secretory defect in non-insulin dependent diabetes mellitus (NIDDM), since forcing islet $\mathrm{pH}_{\mathrm{i}}$ to the optimal range enhances NSIS and induces secretory functions that are normally absent.

\section{Background}

Nutrient-stimulated insulin secretion (NSIS) in the pancreatic $\beta$ cell consists of three distinct components with different underlying mechanisms. These components include a) an initial peak (first phase) triggered by $\mathrm{Ca}^{2+}, \mathrm{b}$ ) augmentation of the $\mathrm{Ca}^{2+}$-triggered response (second phase), and c) a memory that persists after removal of the nutrient, causing enhancement of subsequent secretory responses (time-dependent potentiation) [1-4]. The first phase of the insulin response is initiated by ATP derived 
from glucose metabolism, which leads to membrane depolarization through closure of ATP-dependent $\mathrm{K}^{+}$ channels ( $\mathrm{K}_{\mathrm{ATP}}$ channels) and consequent entry of extracellular $\mathrm{Ca}^{2+}$ through voltage-gated $\mathrm{Ca}^{2+}$ channels. This influx of $\mathrm{Ca}^{2+}$ triggers the release of a small pool of secretory granules, thus producing the initial peak of the insulin response [1]. This peak is followed by a sustained second phase of insulin release that lasts through the duration of exposure to the nutrient, believed to be mediated through augmentation of the $\mathrm{Ca}^{2+}$-triggered firstphase response [1]. Time-dependent potentiation (TDP), a positive memory induced during this acute response, magnifies subsequent secretory responses to all secretagogues $[2,4-6]$.

While any secretagogue that causes an adequate increase in $\mathrm{Ca}^{2+}$ will stimulate the first phase insulin release, the complete range of secretory functions (initiation, augmentation and TDP) can only be produced by compounds that enhance cellular metabolism. The mechanisms underlying the augmentation and memory pathways are poorly understood. Both augmentation and TDP are independent of $\mathrm{K}_{\mathrm{ATP}}$ channels [7-9]. The glucoseinduced augmentation pathway has both $\mathrm{Ca}^{2+}$-dependent and $\mathrm{Ca}^{2+}$-independent components $[10,11]$, while TDP is largely independent of $\mathrm{Ca}^{2+}[12-14]$. These functions show considerable species variation. TDP is present only in certain species such as humans and rats, while the nature of the augmentation response differs between species [1-3,15-17]. Elucidating the mechanisms of these different secretory pathways is important in designing new therapeutic measures for diabetes, since NIDDM affects each pathway differently $[2,5,18]$. TDP is of particular physiological importance. While the direct insulin response to glucose is usually impaired in NIDDM, the potentiating function of glucose can remain intact. In some diabetic subjects, the defective insulin response to glucose can be restored to normal by inducing TDP $[18,19]$. A potential therapeutic approach for such cases is to stimulate TDP by means other than glucose, thus enhancing the secretory ability of the $\beta$ cell and enabling the body to better handle the hyperglycemia. In other forms of NIDDM, both the acute insulin release and TDP are impaired [20-22] and the correction of the defect in the TDP pathway may automatically correct the defect in direct insulin release.

There is strong evidence that NSIS is influenced by $\mathrm{pH}_{\mathrm{i}}$. Most reports on this subject show that a decrease of $\mathrm{pH}_{\mathrm{i}}$ is favorable for GSIS and related functions such as $\mathrm{Ca}^{2+}$ influx and $\mathrm{K}^{+}$retention, while intracellular alkalinization is inhibitory to all these functions [23-31]. The optimal $\mathrm{pH}_{\mathrm{i}}$ for insulin secretion by both glucose and alpha-ketoisocaproate $(\alpha \mathrm{KIC})$ in rat islets is reported to be 0.09 units below basal [32]. Glucose-stimulated TDP in rat islets is critically dependent on an appropriate $\mathrm{pH}_{\mathrm{i}}$ [12], and TDP produced by other mitochondrial fuels also show similar $\mathrm{pH}_{\mathrm{i}}$-dependence [Unpublished observations: SC Gunawardana, YJ Liu, SG Straub and GWG Sharp].

While these studies clearly demonstrate that $\mathrm{pH}_{\mathrm{i}}$ affects insulin secretion, further work is necessary to determine a) the specific components of each secretory pathway affected by $\mathrm{pH}_{\mathrm{i}}$, b) the underlying mechanisms of such effects, and c) the possible therapeutic value of the influence of $\mathrm{pH}_{\mathrm{i}}$ on insulin release. Furthermore, information on the effects of $\mathrm{pH}_{\mathrm{i}}$ in mouse islets is somewhat limited, and, although the majority of the literature indicates that below-basal $\mathrm{pH}_{\mathrm{i}}$ is favorable for insulin secretion, there are some reports to the contrary [32-34]. Such discrepancies may be due to the differences in media and $\mathrm{pH}_{\mathrm{i}}$-measurement techniques used. In this study, using a more accurate modern technique of $\mathrm{pH}_{\mathrm{i}}$-measurement [35], we have investigated the effects of $\mathrm{pH}_{\mathrm{i}}$ on different components of NSIS in mouse islets, and explored the possible mechanisms of such effects. Specific aims were to determine whether $\mathrm{pH}_{\mathrm{i}}$-manipulation would a) enable glucose to induce TDP in mouse islets, where it is normally absent; b) influence direct insulin secretion via both mitochondrial and non-mitochondrial signals; and c) produce changes in cellular metabolism, as indicated by NAD $(\mathrm{P}) \mathrm{H}$ levels.

Our results demonstrate a strong dependence of NSIS on $\mathrm{pH}_{\mathrm{i}}$, and the ability of the appropriate $\mathrm{pH}_{\mathrm{i}}$ to allow secretory functions that are otherwise absent. They also suggest that enhanced nutrient metabolism plays a role in the favorable effects of below-basal $\mathrm{pH}_{\mathrm{i}}$ on NSIS.

\section{Methods \\ Animals}

Male C57BL6 mice aged 4-8 weeks obtained from Harlan Laboratories (Indianapolis, IN) were used for all experiments. The animals were cared for according to the guidelines of the Vanderbilt Institutional Animal Care and Use Committee.

\section{Media}

Islets were isolated in Hanks Balanced Salt solution, and HEPES-buffered Krebs Ringer Bicarbonate solution (KRBH) was used for the major part of the static incubations in secretion experiments. The components of KRBH are as follows: $128.8 \mathrm{mM} \mathrm{NaCl} ; 4.8 \mathrm{mM} \mathrm{KCl} ; 1.2 \mathrm{mM}$ $\mathrm{KH}_{2} \mathrm{PO}_{4} ; 1.2 \mathrm{mM} \mathrm{MgSO}_{4} ; 2.5 \mathrm{mM} \mathrm{CaCl}_{2} ; 5 \mathrm{mM} \mathrm{NaHCO}_{3}{ }^{-}$ and $10 \mathrm{mM}$ HEPES. In the $\mathrm{Cl}-$-free $\mathrm{KRBH}$ medium used for intracellular alkalinization, gluconate salts were used in place of $\mathrm{Cl}^{-}$salts. The medium $\mathrm{pH}$ was maintained at 7.4, except in the media used for intracellular alkalinization where the $\mathrm{pH}$ was raised above 8.3 by addition of $\mathrm{NaOH}$. Basal KRBH used for pre-incubation and non-stimulated 
controls contained $2.8 \mathrm{mM}$ glucose, while the stimulating media contained either $16.7 \mathrm{mM}$ glucose, or other secretagogues as indicated in the presence of $2.8 \mathrm{mM}$ glucose. In $\mathrm{pH}_{\mathrm{i}}$-alteration experiments, $40 \mu \mathrm{M}$ di-methyl amiloride (DMA) was added to the medium to produce intracellular acidification, and a $\mathrm{Cl}^{-}$-free medium, a high $\mathrm{pH}(>8.3)$ medium, or a combination of both, were used for intracellular alkalinization. In preparation for imaging experiments, islets were cultured in RPMI 1640 culture medium supplemented with $10 \%$ fetal bovine serum, $100 \mathrm{U} / \mathrm{ml}$ penicillin, $0.1 \mathrm{~g} / \mathrm{L}$ streptomycin and $11 \mathrm{mM}$ glucose.

\section{Secretagogues}

In addition to $16.7 \mathrm{mM}$ glucose, the following mitochondrial secretagogues were used to stimulate direct insulin secretion. a) methyl pyruvate (MP), the methylated form of the glycolytic end product of glucose, b) leucine, an amino acid metabolized solely in the mitochondria, c) $\alpha \mathrm{KIC}$, a metabolic product of leucine, and d) 2-aminobicyclo[2,2,1]heptane-2-carboxylic acid (BCH), a nonmetabolizable analog of leucine which enhances TCA cycle activity only through allosteric activation of glutamate dehydrogenase (GDH) [36-38]. None of these compounds are metabolized in the cytosol, and their metabolic effects are exerted solely in the mitochondria. The non-mitochondrial secretagogues used were a) high $\mathrm{K}^{+}$, which directly stimulates insulin secretion through depolarization-induced $\mathrm{Ca}^{2+}$-influx, activating the first phase of insulin release, and b) glucose combined with inhibitors that prohibit the entry of glycolytically-derived pyruvate and $\mathrm{NAD}(\mathrm{P}) \mathrm{H}$ into mitochondria, thus eliminating the mitochondrial component of glucose metabolism while leaving the glycolytic component intact [39]. The inhibitors included $\alpha$-hydroxycyanocinnamic acid (CHC), an inhibitor of mitochondrial pyruvate transport, and amino-oxy acetic acid (AOA), an inhibitor of the malate aspartate shuttle that transports glycolytic NAD(P)H into mitochondria [39].

\section{Isolation of islets}

A modified version of the collagenase digestion method described by Lacy and Kostianovsky [40] was used. Mice were anesthetized with intra-peritoneal injection of Ketamine/Xylazine $(80 / 20 \mathrm{mg} / \mathrm{Kg})$. Pancreas was removed, placed in ice-cold Hanks solution and minced with scissors. Collagenase $(3 \mathrm{mg} / \mathrm{ml})$ was added and the mixture shaken in a $37^{\circ} \mathrm{C}$ water bath until the tissue was adequately digested. The mixture was then centrifuged, supernatant removed and the pellet re-suspended in Hanks solution. Centrifugation and re-suspension were repeated several times to remove exocrine tissue. The final pellet was re-suspended either in basal KRBH medium for secretion experiments or RPMI medium for islet culture. Islets were hand picked under a stereomicroscope.

\section{Culture of islets}

The method described by Arkhammar et al. 1998 [41] was used with minor modifications [39,42]. $35 \mathrm{~mm}$ culture dishes with glass-bottomed wells (Mat-Tek corporation) were used. The dishes were pre-prepared by coating the wells with human extracellular matrix (BD Biosciences). Freshly isolated islets were placed carefully in each well, covered with RPMI medium containing $11 \mathrm{mM}$ glucose, and cultured at $37^{\circ} \mathrm{C}$ in $95 \% \mathrm{O}_{2}$ and $5 \% \mathrm{CO}_{2}$. Under these conditions, the cells in the islet spread out within 14 days, greatly reducing the islet thickness and making it particularly suitable for imaging with confocal microscopy. An advantage of this culture technique is that it does not significantly disrupt islet architecture, thus allowing islet cells to maintain normal functions. Although the islet spreads out over the matrix, islet cells do not separate from each other, and the gap junctions between cells continue to function. Islets cultured for two weeks under these conditions exhibit normal responses of $\mathrm{Ca}^{2+}$, $\mathrm{NAD}(\mathrm{P}) \mathrm{H}$ and insulin release to glucose stimulation $[39,41,42]$, providing an excellent model for imaging studies whose results can be safely extrapolated to fresh islets.

\section{Intracellular $\mathrm{pH}$ measurements}

The changes in islet $\mathrm{pH}_{\mathrm{i}}$ produced by each secretagogue and by different $\mathrm{pH}_{\mathrm{i}}$-alteration techniques were monitored by confocal microscopy, using carboxy-seminaphthorhodofluor-5 (SNARF5) [35], a pH-sensitive fluorescent indicator. Prior to imaging, cultured islets were maintained in RPMI medium containing $5 \mathrm{mM}$ glucose for 48 hours. On the day of the experiment, RPMI medium was removed, and islets were washed and placed in basal KRBH medium. SNARF5-AM ( $5 \mu \mathrm{M}$ final concentration) was added and incubated for one hour at $37^{\circ} \mathrm{C}$. Loaded islets were placed on a warmed stage in a humidified and temperature-controlled chamber at $37^{\circ} \mathrm{C}$, and monitored with a F-Fluar $40 \times 1.3$ NA oil immersion lens of a LSM510 confocal laser-scanning microscope (Zeiss). Islets were excited at $514 \mathrm{~nm}$ with an argon laser, and the emission fluorescence was collected in the band-widths 568-589 $\mathrm{nm}$ and 621-643 $\mathrm{nm}$ (peak emission at 580 and $630 \mathrm{~nm}$ ) using the Meta detector (Zeiss). Time-series images $(2.56 \mu \mathrm{s} /$ pixel) were collected for 5-20 minutes as was suitable for each experiment. A stable baseline was obtained before the actual recording for each experimental condition started. LSM software was used to calculate the ratio between the two emission fluorescence values from selected well-loaded regions in each islet. This ratio was proportional to the islet $\mathrm{pH}_{\mathrm{i}}$. The results were analyzed using LSM software, Graphpad Prism, and Microsoft Excel. One representative recording for each experimental condition is shown in the results section, and the value $n$ denotes the number of recordings done with different islets for each condition. The $\mathrm{pH}_{\mathrm{i}}$ change for each 
condition is the difference between the average $\mathrm{pH}_{\mathrm{i}}$ of the baseline and the average $\mathrm{pH}_{\mathrm{i}}$ over a stable region of the recording after treatment. The $\mathrm{pH}_{\mathrm{i}}$ changes from $\mathrm{n}$ recordings were averaged to obtain the "average $\mathrm{pH}_{\mathrm{i}}$ change" shown in the results section and in the legend for each figure. A standard curve was prepared by fixing the islet $\mathrm{pH}_{\mathrm{i}}$ at known values (ranging from 5.5 to 9, with 5-10 islets for each $\mathrm{pH}$ ), using a KRBH medium containing $100 \mathrm{mM}$ $\mathrm{K}^{+}$and $20 \mathrm{mM}$ nigericin to equilibrate the $\mathrm{pH}$ inside and outside cells.

\section{Secretion measurements}

All incubations were done in a $37^{\circ} \mathrm{C}$ water bath. Freshly isolated islets were pre-incubated for one hour in basal $\mathrm{KRBH}$ containing $2.8 \mathrm{mM}$ glucose. Islets were then divided into groups and stimulated with different compounds as indicated in the results section, for one hour. Control group was maintained in basal glucose. At the end of the stimulation period, samples were collected for insulin measurement by radio-immuno-assay (performed by the DRTC Core facility at Vanderbilt University). Islet insulin content was measured after freezing islets overnight in $2 \%$ Triton-X. Insulin secretion was expressed as fractional release, i.e. the percentage of total insulin content released over the period of stimulation. In the experiments monitoring TDP, after pre-incubation islets were exposed to high $(16.7 \mathrm{mM})$ glucose with or without intracellular acidification for 40 minutes, while the control group was exposed to basal glucose. Subsequently all groups were rested in basal glucose for 30 minutes, and stimulated with high glucose for one hour prior to collection of samples for insulin assay. The value $\mathrm{n}$ denotes the number of times each experiment was repeated using islets from different mice.

\section{Imaging of $\mathrm{NAD}(\boldsymbol{P}) \mathrm{H}$}

Experiments were performed using TPEM combined with techniques developed in our lab. a) Two-photon fluorescence imaging: Prior to imaging, cultured islets were maintained in RPMI medium containing $5 \mathrm{mM}$ glucose for 2448 hours. On the day of the experiment, RPMI medium was removed, and islets were washed and placed in basal KRBH medium. Two-photon imaging was done using a Plan-Apochromat $60 \times 1.4 \mathrm{NA}$ oil immersion lens of a LSM510 confocal laser-scanning microscope (Zeiss). Islets were kept at $37^{\circ} \mathrm{C}$ and high humidity using a temperature controlled stage and objective warmer (Zeiss). Sequential images of autofluorescence were collected using $710 \mathrm{~nm}$ excitation with a Coherent Mira laser tuned to $710 \mathrm{~nm}$. Each image was collected with a single scan using slow speed $(6.4 \mu \mathrm{s} /$ pixel) and $0.1 \mu \mathrm{m} /$ pixel. The laser power used provides $\sim 3.5 \mathrm{~mW}$ to the surface, at which power no observable damage is caused to the islet [43] even after 60 minutes of continuous imaging [44]. Non-descanned $\mathrm{NAD}(\mathrm{P}) \mathrm{H}$ fluorescence was collected through a custom
380- to 550-nm filter (Chroma). b) Standard Curve: Standard solutions of NADH bound to yeast alcohol dehydrogenase were imaged in deep well slides using live cell data collection settings. This solution closely resembles cellular $\mathrm{NAD}(\mathrm{P}) \mathrm{H}$ since a majority of $\mathrm{NAD}(\mathrm{P}) \mathrm{H}$ is enzyme bound in the cellular environment [45]. NADH was titrated into a solution of $\sim 100 \mathrm{mg} / \mathrm{ml}$ alcohol dehydrogenase, $10 \mathrm{mM}$ ethanol, $100 \mathrm{mM}$ isobutyramide, $6 \mathrm{mM}$ semicarbazide, and $10 \mathrm{mM}$ HEPES (pH 9.0). c) Image Analysis: Images were exported in tagged image file format (tiff) for analysis using MetaMorph software (version 5.0). Images were filtered using a $5 \times 5$ median filter. An intensity threshold was first set in the NAD $(\mathrm{P}) \mathrm{H}$ image to isolate the bright mitochondria. In each image the maximum intensity from the mitochondrial regions was averaged. This average represents the best average intensity of the in focus mitochondria for the image. A threshold was set on the median filtered image to isolate cytoplasmic NAD $(\mathrm{P}) \mathrm{H}$ intensity. The low end of this threshold excluded nuclear regions and the high end partially excluded brighter mitochondrial regions. A binary mask was made from the threshold. This mask was then eroded, dilated, and segmented to remove noise pixels in the background regions and generate a number of cytoplasmic regions. These regions were transferred to the median filtered image and the mean intensity of these regions was calculated as the average cytoplasmic NAD(P)H intensity.

\section{Statistical analysis}

Values are expressed as mean \pm SEM. Groups were compared using paired Student's $t$ test. In secretion studies, $\mathrm{n}$ denotes the number of times each experiment was repeated with islets from different mice. In imaging experiments for $\mathrm{pH}_{\mathrm{i}}$ and $\mathrm{NAD}(\mathrm{P}) \mathrm{H}$, $\mathrm{n}$ denotes the number of islets imaged for each condition.

\section{Results}

\section{SNARF5-AM as a $\mathrm{pH}_{i}$-indicator for islets}

SNARF5-AM loaded efficiently into a significant portion of the $\beta$ cell-rich region of each islet, and emitted bright fluorescence when excited at $514 \mathrm{~nm}$. Changes in the emission ratio $630 / 580$ were directly proportional to changes in islet $\mathrm{pH}_{\mathrm{i}}$, indicating SNARF5-AM to be a suitable dye to monitor $\mathrm{pH}_{\mathrm{i}}$ in mouse islets. (Fig. 1). The basal $\mathrm{pH}_{\mathrm{i}}$ in islets (in KRBH with basal glucose) fell within the range of 6.9-7.2 with an average of $7.09 \pm 0.01(n=72)$, and remained stable until additions/changes were made.

\section{Selecting methods for $\mathrm{pH}_{i}$-alteration}

We tested several traditional methods of $\mathrm{pH}_{\mathrm{i}}$-alteration, including the addition of weak acids or amiloride derivatives (inhibitors of the $\mathrm{Na}^{+} / \mathrm{H}^{+}$exchanger) for acidification, and addition of weak bases, removal of medium $\mathrm{Cl}^{-}$ , or raising the medium $\mathrm{pH}$ for intracellular alkalinization. The $\mathrm{pH}_{\mathrm{i}}$ changes produced by weak acids or bases 


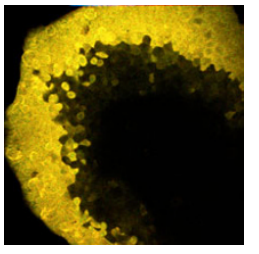

$\mathrm{pH} 6$

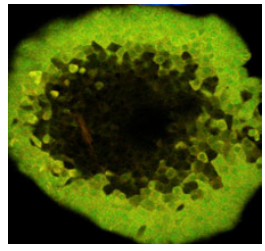

$\mathrm{pH} 7$
$\mathrm{pH} 8$

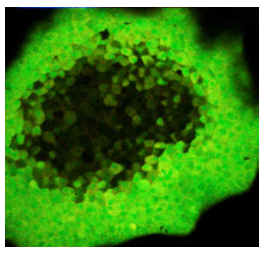

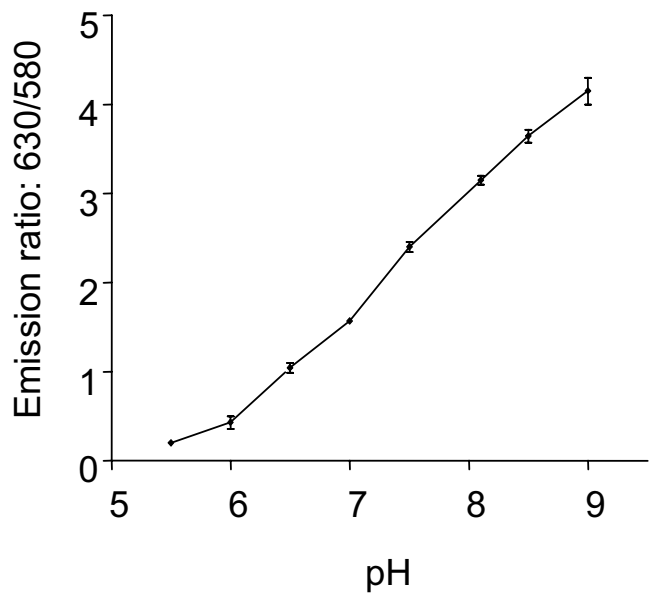

Figure I

Changes in emission fluorescence of SNARF5, in response to changes in intracellular $\mathrm{pH}$ : Islets loaded with SNARF5-AM $(5 \mu \mathrm{M})$ were fixed at known intracellular $\mathrm{pH}$ values by placing them in $\mathrm{KRBH}$ solutions containing 100 $\mathrm{mM} \mathrm{K}^{+}$and $20 \mu \mathrm{M}$ nigericin, adjusted to different $\mathrm{pH}$ values. Islets were excited at $514 \mathrm{~nm}$, and emission fluorescence recorded at 580 and $630 \mathrm{~nm}$. Emission fluorescence at 580 and $630 \mathrm{~nm}$ are denoted by red and green respectively. Top:

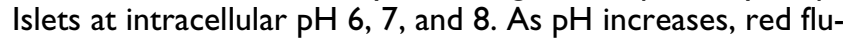
orescence decreases and green fluorescence increases. Bottom: Standard curve prepared using islets fixed at $\mathrm{pH}_{\mathrm{i}}$ values ranging from 5.5-9.0. $\mathrm{n}=5-10$ islets for each $\mathrm{pH}$.

were sharp but very transient (data not shown), making these methods unsuitable for altering $\mathrm{pH}_{\mathrm{i}}$ over a long period. In contrast, DMA produced a slow, steady and sustained decrease of $\mathrm{pH}_{\mathrm{i}}$, bringing it down by $0.2-1.0 \mathrm{pH}$ units from baseline, with an average decrease of $0.5 \pm 0.07$ $\mathrm{pH}$ units (Fig. 2A). Removal of medium $\mathrm{Cl}^{-}$, or raising the medium $\mathrm{pH}$ above 8.3, both produced sustained increases in $\mathrm{pH}_{\mathrm{i}}$, but the magnitude of the change was small, ranging from 0.1-0.4 units, with an average increase of $0.3 \pm$ 0.05 and $0.24 \pm 0.03$, respectively (Fig. $2 \mathrm{~B} \& 2 \mathrm{C}$ ). Therefore, none of the traditional $\mathrm{pH}_{\mathrm{i}}$-increasing methods
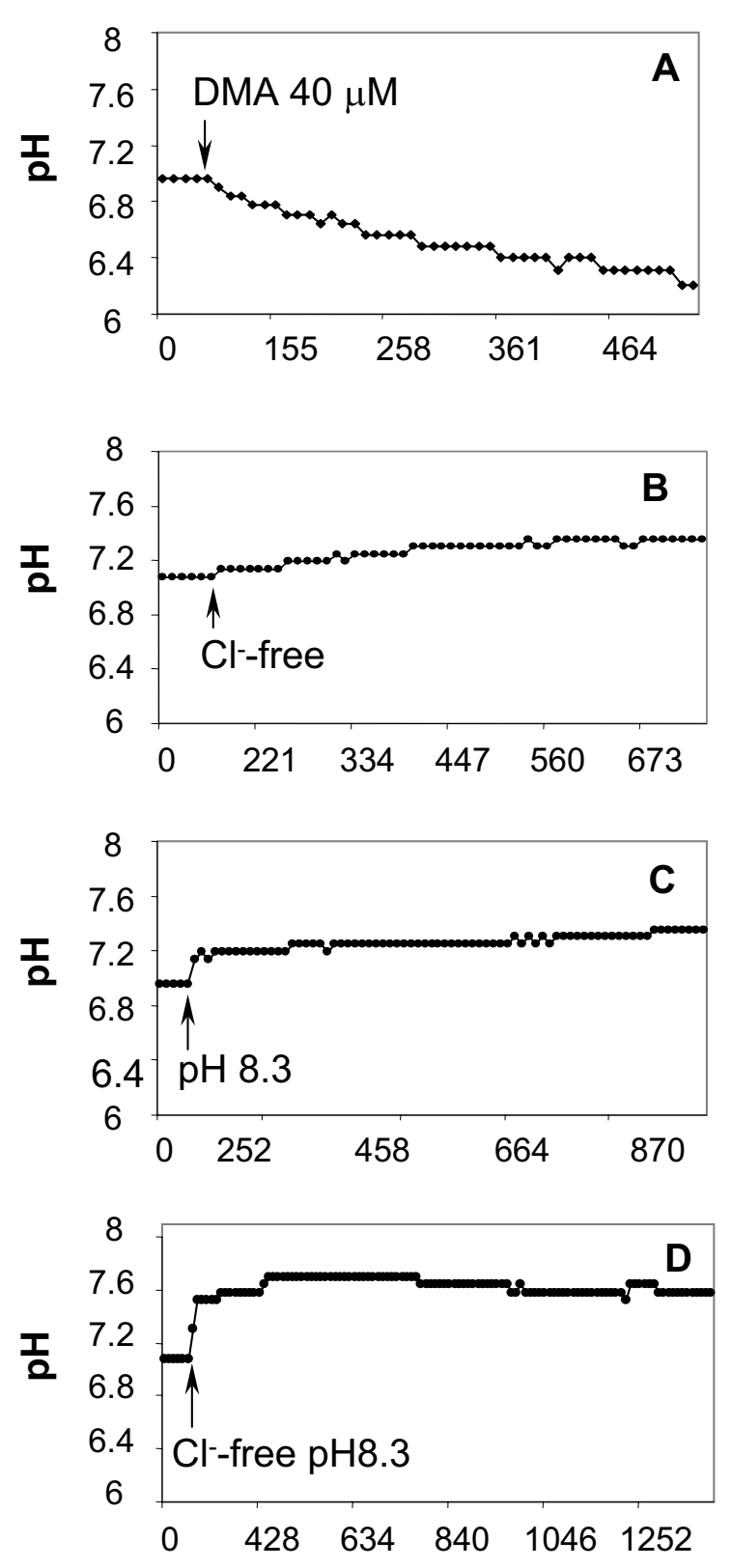

Time (seconds)

Figure 2

Effect on islet $\mathrm{pH}_{\mathrm{i}}$ by different $\mathrm{pH}$-altering methods: Islets loaded with SNARF5-AM were placed in basal KRBH, excited at $5 \mathrm{I} 4 \mathrm{~nm}$ and emission fluorescence recorded at 580 and $630 \mathrm{~nm}$. After a steady baseline was established, additions/substitutions were made as denoted in each figure. One representative recording for each condition is shown. A. $40 \mu$ M DMA: $n=16$, average $\mathrm{pH}$ change $=0.5 \pm 0.07$; $\mathrm{B}$. Removal of medium Cl: $\mathrm{n}=5$, average $\mathrm{pH}$ change $=0.3 \pm$ 0.06 ; C. Switching to a high $\mathrm{pH}(>8.3)$ medium: $n=6$, average $\mathrm{pH}$ change $=0.24 \pm 0.03 ; \mathrm{D}$. Switching to a $\mathrm{Cl}-$-free and high $\mathrm{pH}(>8.3)$ medium: $\mathrm{n}=8$, average $\mathrm{pH}$ change $=0.5 \pm 0.06$ 


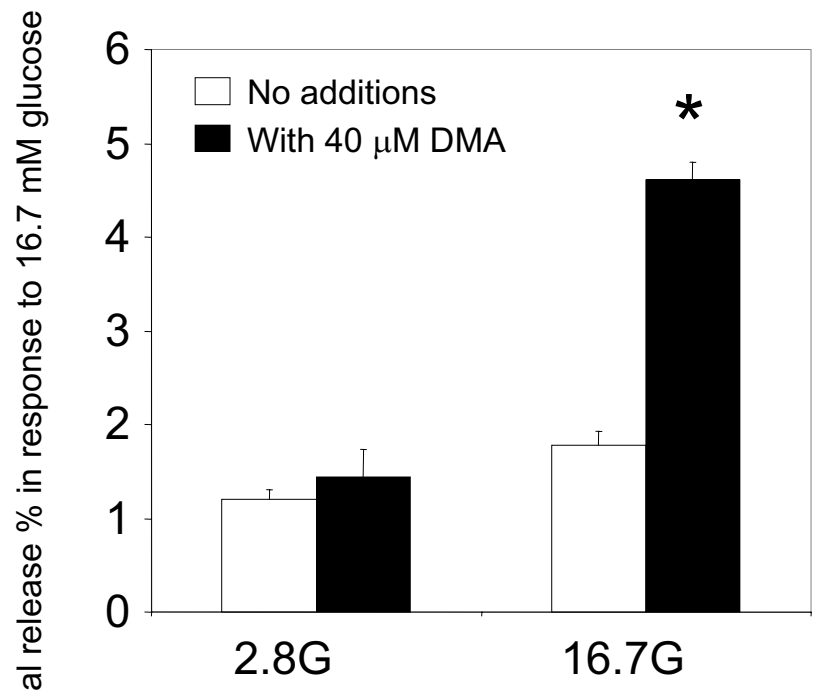

Previous Exposure

Figure 3

Glucose induces TDP in mouse islets in the presence of DMA: Insulin secretion in response to $16.7 \mathrm{mM}$ glucose, from freshly isolated islets that were previously exposed to different conditions as denoted in the $X$ axis. All groups were first pre-incubated in basal glucose for one hour. During the next 40 minutes, islets were exposed to 2.8 or $16.7 \mathrm{mM}$ glucose with and without $40 \mu \mathrm{M}$ DMA. Following a subsequent rest period of 30 minutes in basal glucose, all groups were exposed to $16.7 \mathrm{mM}$ glucose for one hour and samples collected for insulin assay. Insulin secretion is expressed as fractional release $\%$, i.e. the percentage of the total insulin content released over the one-hour period of stimulation with 16.7 mM glucose. $\mathrm{n}=8$; $\mathrm{G}=\mathrm{mM}$ glucose; $*=\mathrm{p}<$ $0.000 \mathrm{I}$, compared with all other groups.

appeared suitable for producing a sufficient increase in $\mathrm{pH}_{\mathrm{i}}$ for one hour. However, combination of the latter two methods, i.e. using a $\mathrm{Cl}^{-}$-free high $\mathrm{pH}$ medium, proved to be an effective technique for prolonged increase of $\mathrm{pH}_{\mathrm{i}}$ by $0.3-0.7$ units, with an average change of $0.5 \pm 0.06$. (Fig. 2D)

\section{Effect of $\mathrm{pH}_{i}$ on glucose-induced TDP}

As has been shown before, TDP does not occur in mouse islets [15-17]. Remarkably, glucose induced a strong TDP response in mouse islets in the presence of intracellular acidification by DMA (Fig. 3). In other words, while the secretory response in mouse islets is not normally affected by a previous exposure to glucose, it was greatly magnified when the previous exposure to glucose was combined with lowered $\mathrm{pH}_{\mathrm{i}}$. It is noteworthy that the $\mathrm{pH}_{\mathrm{i}}$ change caused by DMA does not persist once DMA is removed from the medium (data not shown), so that the enhancement of the subsequent secretory response to glucose is caused purely by a memory effect. Since lowering $\mathrm{pH}_{\mathrm{i}}$ can induce/unmask a secretory function which is normally absent, it is very likely that $\mathrm{pH}_{\mathrm{i}}$ has a strong influence on direct insulin secretion as well.

\section{Effect of $\mathrm{pH}_{\mathrm{i}}$-alteration on direct insulin secretion by mitochondrial secretagogues, and effect of different mitochondrial fuels on $\mathrm{pH}_{i}$}

Previous studies have shown that GSIS is enhanced by intracellular acidification and inhibited by intracellular alkalinization [23-32]. Our preliminary studies confirmed this, and showed that even weak methods of alkalinization (such as removal of medium $\mathrm{Cl}^{-}$or raising the medium $\mathrm{pH}$ above 8.3) significantly inhibit GSIS (Fig. 4A).

Among the mitochondrial secretagogues tested, leucine, $\alpha \mathrm{KIC}$ (metabolic product of leucine) and $\mathrm{BCH}$ (nonmetabolizable analog of leucine) all produced significant insulin secretion, to a lesser degree than glucose. As expected, insulin secretion by all these agents showed a strong correlation with $\mathrm{pH}_{\mathrm{i}}$. Decrease of $\mathrm{pH}_{\mathrm{i}}$ by DMA caused a marked increase in the insulin secretion, making the magnitude of the secretory response close to that of glucose. Insulin release by all three agents was significantly inhibited by a strong increase in $\mathrm{pH}_{\mathrm{i}}$, as produced by a Cl-free high $\mathrm{pH}$ medium (Fig. 4B,4C \&4D).

Interestingly, weaker methods of alkalinization were not sufficient to inhibit the insulin release by leucine, KIC and $\mathrm{BCH}$, unlike with glucose (data not shown). This difference can be explained by the direct effect of each nutrient on intracellular pH. As shown in Table 1, glucose produced a significant increase in $\mathrm{pH}_{\mathrm{i}}$. This was further increased even by weaker methods of alkalinization, so that high glucose in a high $\mathrm{pH}$ medium (Table 1 ) or $\mathrm{Cl}^{-}$free medium (data not shown) resulted in a prolonged increase of $\mathrm{pH}_{\mathrm{i}}$ to 7.5 or higher. A high $\mathrm{pH}$ medium (Table 1) or $\mathrm{Cl}^{-}$-free medium (data not shown) alone was not adequate to produce such a rise in $\mathrm{pH}_{\mathrm{i}}$, with or without the presence of other fuels such as leucine, $\mathrm{BCH}$ or $\alpha \mathrm{KIC}$. Therefore, while any method of alkalinization combined with glucose can drive the $\mathrm{pH}_{\mathrm{i}}$ above the range favorable for secretion, weaker methods of alkalinization still maintain the $\mathrm{pH}_{\mathrm{i}}$ within this favorable range in the presence of other mitochondrial fuels (Table 1). Insulin release by these compounds could be inhibited only when $\mathrm{pH}_{\mathrm{i}}$ was driven above 7.5 by a $\mathrm{Cl}^{-}$-free high $\mathrm{pH}$ medium (Fig. 4B,4C \&4D). 

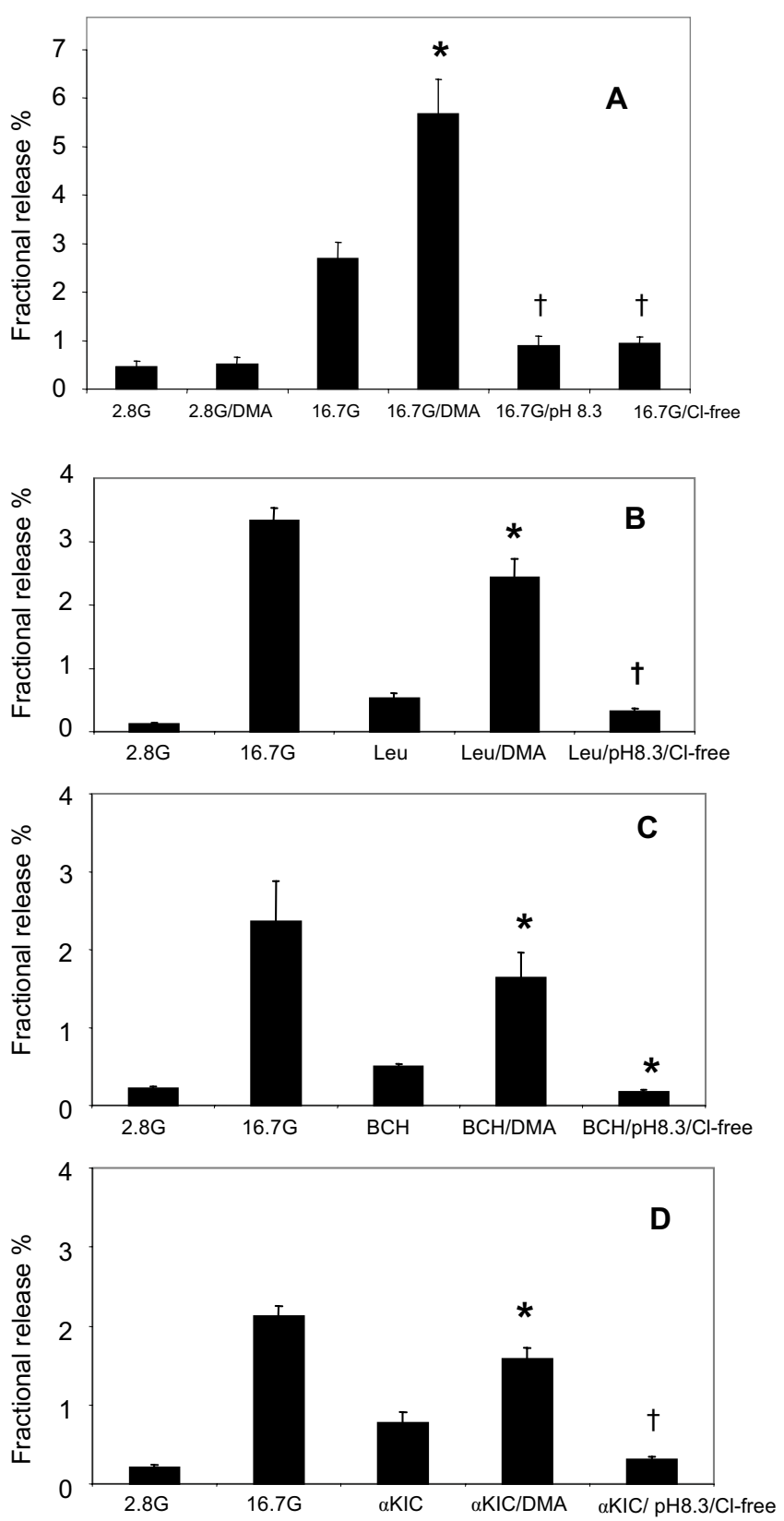

Stimulating agent

Figure 4

Effect of experimental alteration of $\mathrm{pH}_{\mathrm{i}}$ on direct insulin secretion by mitochondrial secretagogues: Insulin secretion from freshly isolated islets, in response to different secretagogues as indicated, with and without intracellular $\mathrm{pH}$ altered. Controls are in $2.8 \mathrm{mM}$ and $16.7 \mathrm{mM}$ glucose, and test groups are in leucine, $\alpha \mathrm{KIC}$ or BCH, $20 \mathrm{mM}$ each. Intracellular acidification was produced by $40 \mu \mathrm{M}$ DMA. Intracellular alkalinization was produced by either a $\mathrm{Cl}^{-}-$free medium $(\mathrm{A})$, a high $\mathrm{pH}$ $(>8.3)$ medium $(A)$, or a combination of both (B-D). All groups were first pre-incubated in basal glucose for one hour, and subsequently exposed to each condition denoted in the $X$ axes for one hour, followed by sample collection for insulin assay. Insulin secretion is expressed as fractional release \%, i.e. the percentage of the total insulin content released over the one-hour period of stimulation with different agents. $G=m M$ glucose; Leu = leucine. A) Glucose: $n=6$; $*=p<0.00 I$; and $\dagger=p<0.05$, compared to stimulated control in high glucose without $\mathrm{pH}_{\mathrm{i}}$-alteration. $\mathrm{B}$ ) Leucine: $\mathrm{n}=5$; $*=p<0.00 \mathrm{I}$, and $\dagger=p<0.05$, compared to leucine without $\mathrm{pH}_{\mathrm{i}}$-alteration. C) $\mathrm{BCH}: \mathrm{n}=5$; $*=\mathrm{p}<0.00 \mathrm{I}$, compared to $\mathrm{BCH}$ without $\mathrm{pH}$-alteration. D) $\alpha \mathrm{KIC}$ : $\mathrm{n}=$ $8 ; *=p<0.001$, and $t=p<0.05$, compared to $\alpha \mathrm{KIC}$ without $\mathrm{pH}_{\mathrm{i}}$-alteration. 
Table I: Islet $\mathrm{pH}_{\mathrm{i}}($ mean \pm SEM) in the presence of each secretagogue

\begin{tabular}{lll}
\hline Nutrient & In Basal pH medium & In High pH medium \\
\hline Glucose $16.7 \mathrm{mM}$ & $7.32 \pm 0.04$ & $7.55 \pm 0.03$ \\
Leucine $20 \mathrm{mM}$ & $7.09 \pm 0.03$ & $7.23 \pm 0.04$ \\
BCH 20 mM & $7.06 \pm 0.03$ & $7.24 \pm 0.03$ \\
$\alpha$ KIC 20 mM & $6.99 \pm 0.02$ & $7.18 \pm 0.03$ \\
\hline
\end{tabular}

Islets loaded with SNARF5-AM were placed in KRBH medium of either basal pH (7.4) or high pH (8.3), containing each secretagogue. Islets were excited at $514 \mathrm{~nm}$ and emission fluorescence recorded at 580 and $630 \mathrm{~nm}$. Average intracellular $\mathrm{pH}$ was calculated over a stable region of each recording, and these values from $\mathrm{n}$ recordings were averaged to obtain the $\mathrm{pH}$ values shown in the table. $\mathrm{n}=10$ for glucose; 6 for leucine and $\mathrm{BCH}$; 5 for $\alpha \mathrm{KIC}$.

The inability of pyruvate to stimulate insulin release is puzzling, and has been widely studied [39,46,47]. We used the methylated form of pyruvate (MP), which is known to penetrate cellular membranes better than pyruvate [48-51], as one of the mitochondrial stimulants. In our hands, MP did not stimulate insulin secretion, with or without acidification by DMA (Fig. 5A). Interestingly, MP caused a dramatic and prolonged decrease in $\mathrm{pH}_{\mathrm{i}}$ (ranging from 0.7-1.7 units from baseline, with an average decrease of $1.0 \pm 0.08 \mathrm{pH}$ units), providing a possible explanation for its lack of secretion (Fig. 5B). If the lack of secretion by MP is due to inappropriately low $\mathrm{pH}_{\mathrm{i}}$, then a forced increase of $\mathrm{pH}_{\mathrm{i}}$ should allow it to stimulate insulin release. While the weaker methods of alkalinization were not adequate to reverse the acidifying effect of $\mathrm{MP}$, a Cl-free high $\mathrm{pH}$ medium did reverse it, bringing the $\mathrm{pH}$ back to the range of $6.4-7.0$ (Fig. 5C,5D \&5E). As expected, reversing the acidifying effect of MP by a $\mathrm{Cl}^{-}$-free high $\mathrm{pH}$ medium did allow MP to stimulate significant insulin secretion. (Fig. 5F).

\section{Effect of $\mathrm{pH}_{i}$-alteration on direct insulin secretion by non- mitochondrial secretagogues}

High $\mathrm{K}^{+}$causes insulin exocytosis via depolarizationinduced $\mathrm{Ca}^{2+}$-influx, and does not involve nutrient metabolism or ATP production. $\mathrm{K}^{+}$-induced insulin secretion was slightly but not significantly enhanced by intracellular acidification, and was not affected by alkalinization (Fig. 6A).

Glucose is converted to a non-miotchondrial secretagogue by combining with the mitochondrial inhibitors AOA and CHC [39]. As expected, the presence of these inhibitors caused a significant reduction in the insulin response by glucose. Remarkably, intracellular acidification by DMA not only reversed this inhibition, but enhanced the insulin secretion further than that produced by glucose alone (Fig. 6B). This suggests that the effect of $\mathrm{pH}_{\mathrm{i}}$ is not limited to mitochondrially-derived signals, and that extra-mitochondrial signals alone can induce significant insulin secretion when $\mathrm{pH}_{\mathrm{i}}$ is within the favorable range.

\section{Effect of intracellular acidification on cellular $N A D(P) H$ levels}

To explore the mechanisms whereby DMA reversed the inhibition of GSIS by AOA and CHC, we monitored insulin secretion and cellular $\mathrm{NAD}(\mathrm{P}) \mathrm{H}$ response in the presence/absence of DMA and the inhibitors. While DMA enables glucose to stimulate insulin release in the presence of inhibitors (Fig. 6B), DMA alone does not stimulate insulin secretion (Fig. 4A). As shown in fig. 7, however, DMA did increase whole cell NAD $(\mathrm{P}) \mathrm{H}$ levels in all situations tested, including basal or high glucose with and without inhibitors. It is interesting that DMA increased $\mathrm{NAD}(\mathrm{P}) \mathrm{H}$ at basal glucose levels (Open bars: no additions vs. DMA, and AOA/CHC vs. AOA/CHC/DMA). This is likely due to an increase in NADPH rather than $\mathrm{NADH}$, based on the fact that DMA alone does not cause insulin secretion. High glucose induced similar increases in $\mathrm{NAD}(\mathrm{P}) \mathrm{H}$ in the absence or presence of DMA, suggesting that DMA does not stimulate glucose utilization beyond normal. However, when glucose metabolism is inhibited with $\mathrm{AOA}$ and $\mathrm{CHC}$, DMA treatment allowed glucose to induce similar changes as those observed in the absence of the inhibitors. This suggests that DMA treatment somehow enables the full utilization of glucose. To further investigate the metabolic effect of low $\mathrm{pH}_{\mathrm{i}}$, we looked at the effect of DMA on cytosolic and mitochondrial $\mathrm{NAD}(\mathrm{P}) \mathrm{H}$ levels in the presence and absence of nutrients whose secretory ability is enhanced at low $\mathrm{pH}_{\mathrm{i}}$. Both in the presence and absence of nutrients $(16.7 \mathrm{mM}$ glucose or $20 \mathrm{mM} \alpha \mathrm{KIC})$, DMA produced a dramatic increase in cytoplasmic $\mathrm{NAD}(\mathrm{P}) \mathrm{H}$ levels (Fig. 8A), and a smaller but significant increase in the mitochondrial $\mathrm{NAD}(\mathrm{P}) \mathrm{H}$ levels (Fig. 8B). Again, glucose-induced increases in the NAD $(\mathrm{P}) \mathrm{H}$ response (both cytoplasmic and mitochondrial) were of similar magnitude in the absence or presence of DMA.

\section{Discussion}

Even though the influence of $\mathrm{pH}_{\mathrm{i}}$ on GSIS has been known for many years, there is some controversy on the nature of these effects, and little attention has been paid 

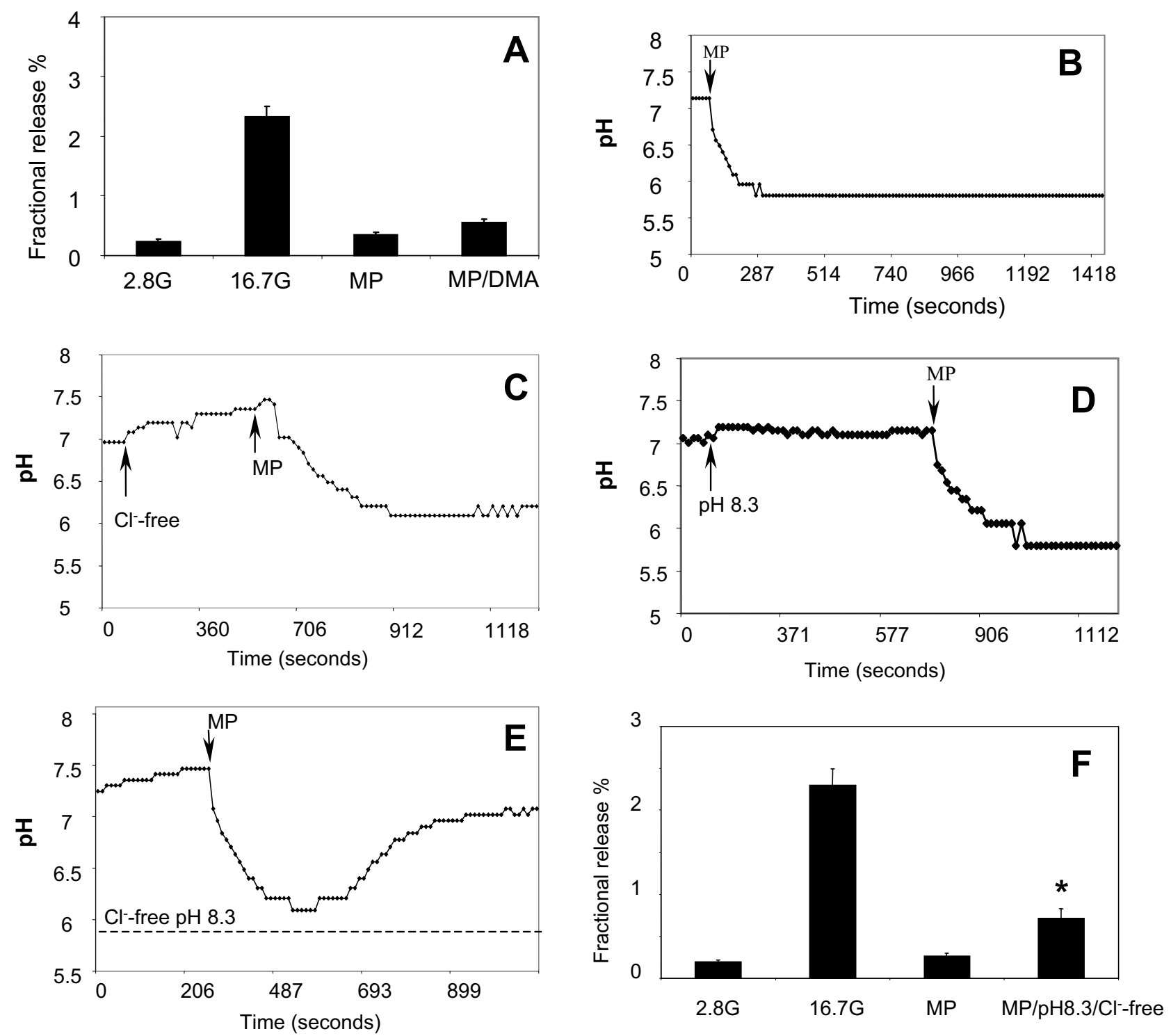

Figure 5

Insulin secretion and $\mathbf{p H}_{\mathbf{i}}$-changes produced by MP: A. MP does not stimulate insulin release, even with intracellular acidification: Insulin secretion in response to $20 \mathrm{mMMP}$ with and without intracellular acidification, from freshly isolated islets. Controls were exposed to $2.8 \mathrm{mM}$ and $16.7 \mathrm{mM}$ glucose. All groups were first pre-incubated in basal glucose for one hour, and subsequently exposed to each condition denoted in the $X$ axis for one hour, followed by sample collection for insulin assay. Insulin secretion is expressed as fractional release \%, i.e. the percentage of the total insulin content released over the one-hour period of stimulation with different agents. Intracellular acidification was produced by addition of $40 \mu M D M A$. G $=\mathrm{mM}$ glucose. $n=6$. B. MP produces a drastic decrease in intracellular $\mathrm{pH}$ : Islets loaded with SNARF5-AM were placed in basal KRBH, excited at $514 \mathrm{~nm}$ and emission fluorescence recorded at 580 and $630 \mathrm{~nm}$. After a steady baseline was established, $20 \mathrm{mM}$ MP was added where indicated. One representative recording is shown. $n=16$; average decrease in $\mathrm{pH}_{\mathrm{i}}=\mathrm{I} .0 \pm 0.08$. $\mathrm{C}$ and $\mathrm{D}$. $\mathrm{MP}$ induced acidification is not affected by traditional methods of alkalinization: Same procedure as in $\mathrm{B}^{-}$. Islets were switched to $\mathrm{Cl}^{-}$ -free medium (C) or high $\mathrm{pH}(>8.3)$ medium (D), as indicated, before addition of MP. One representative recording for each condition is shown. $\mathrm{C}: \mathrm{n}=3$; $\mathrm{D}: \mathrm{n}=4$. $\mathrm{E}$. MP-induced acidification is reversed by a Cl--free high $\mathrm{pH}$ medium: Islets loaded with SNARF5-AM were placed in $\mathrm{Cl}^{-}$-free $\mathrm{KRBH}$ of $\mathrm{pH}$ above 8.3, excited at $5 \mathrm{I} 4 \mathrm{~nm}$ and emission fluorescence recorded at 580 and

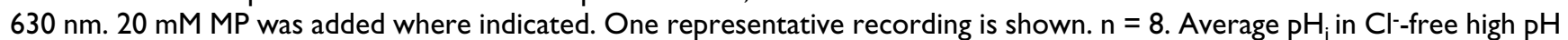
medium $=7.5 \pm 0.04$; Average lowest $\mathrm{pH}_{\mathrm{i}}$ after addition of $\mathrm{MP}=6.1 \pm 0.12$; Average $\mathrm{pH}_{\mathrm{i}}$ after recovery $=6.9 \pm 0.1 ; \mathrm{pH}_{\mathrm{i}}$ range after recovery $=6.4-7.0 \mathrm{~F}$. MP stimulates insulin secretion when $\mathrm{pH}_{\mathrm{i}}$ is brought back to 6.4-7.0 by strong alkalinization: Same procedure as in $\mathrm{A}$. Intracellular alkalinization was produced by exposure to a $\mathrm{Cl}^{-}$-free high $\mathrm{pH}(>8.3)$ medium. $\mathrm{G}=\mathrm{mM}$ glucose; $\mathrm{n}=8 ; *=\mathrm{p}<0.00 \mathrm{I}$, compared to MP without alkalinization or basal glucose control. 

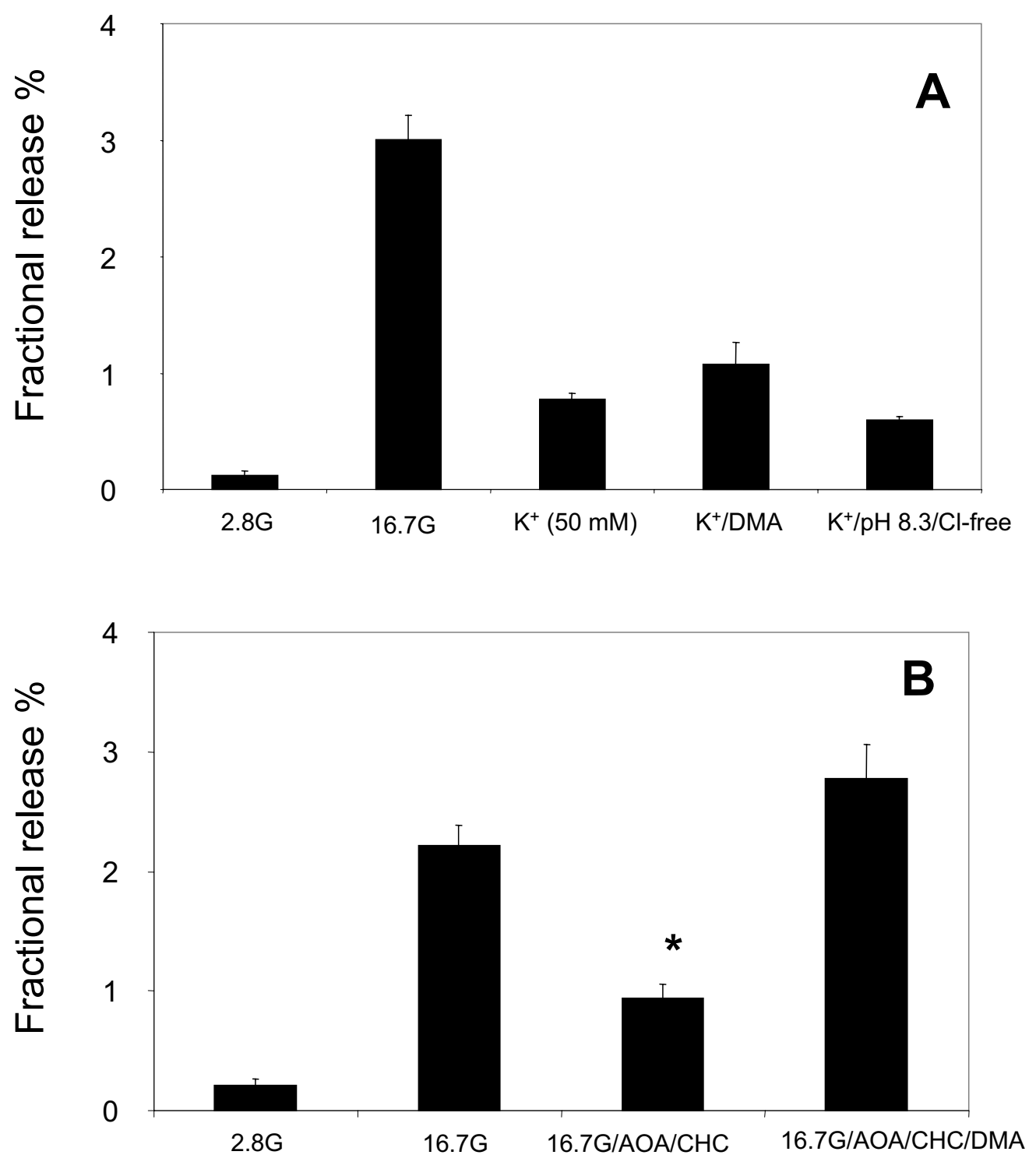

\section{Stimulating agent}

\section{Figure 6}

Effect of experimental alteration of $\mathrm{pH}_{\mathrm{i}}$ on insulin secretion by non-mitochondrial secretagogues: $\mathrm{A}$. Insulin

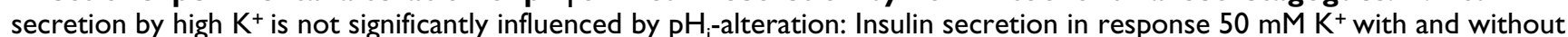
$\mathrm{pH}_{\mathrm{i}}$-alteration techniques (40 $\mu$ M DMA for acidification and a Cl--free high $\mathrm{pH}$ medium for alkalinization) from freshly isolated islets. Control groups were exposed to $2.8 \mathrm{mM}$ and $16.7 \mathrm{mM}$ glucose. All groups were first pre-incubated in basal glucose for one hour, and subsequently exposed to each condition denoted in the $\mathrm{X}$ axis for one hour, followed by sample collection for insulin assay. Insulin secretion is expressed as fractional release \%, i.e. the percentage of the total insulin content released over the one-hour period of stimulation with different agents. $n=7 ; G=m M$ glucose. $B$. GSIS is inhibited by AOA and CHC. This inhibition is reversed by DMA: Insulin secretion in response to glucose combined with AOA and $\mathrm{CHC}$ ( $5 \mathrm{mM}$ each) in the presence or absence of $40 \mu \mathrm{M}$ DMA, from freshly isolated islets. All groups were first pre-incubated in basal glucose for one hour, and subsequently exposed to each condition denoted in the $X$ axis for one hour, followed by sample collection for insulin assay. Insulin secretion is expressed as fractional release \%, i.e. the percentage of the total insulin content released over the one-hour period of stimulation with different agents. $G=m M$ glucose. $n=5 ; *=p<0.00$ I, compared with high glucose alone, or with high glucose with inhibitors and DMA added. 


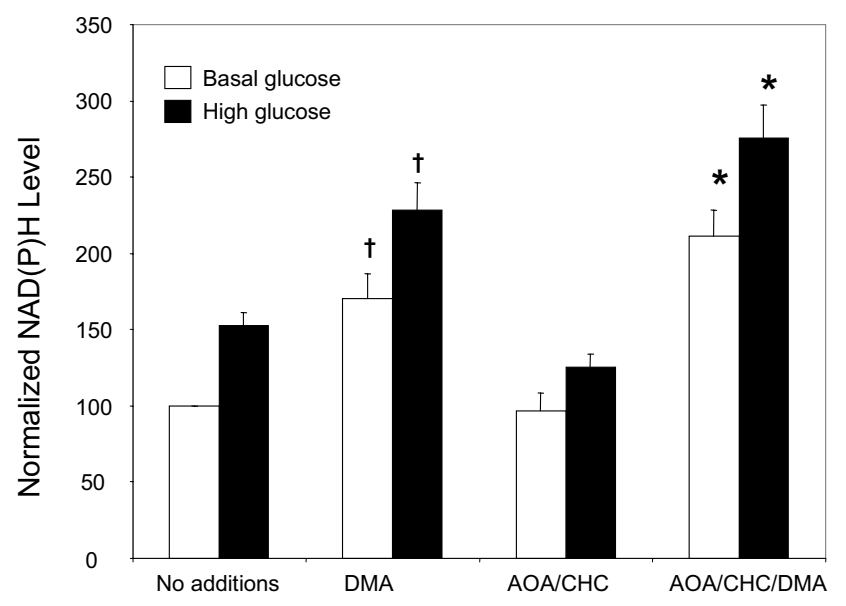

Figure 7

DMA increases whole cell $\mathbf{N A D}(\mathbf{P}) \mathrm{H}$, both in the presence and absence of inhibitors: Islets were placed in basal KRBH with or without mitochondrial inhibitors (AOA and $\mathrm{CHC}, 5 \mathrm{mM}$ each) and/or $40 \mu \mathrm{M} \mathrm{DMA}$, and $\mathrm{NAD}(\mathrm{P}) \mathrm{H}$ auto-fluorescence was measured by TPEM before and after addition of $16.7 \mathrm{mM}$ glucose. $\mathrm{NAD}(\mathrm{P}) \mathrm{H}$ auto-fluorescence for each condition is expressed as a percentage of the control (basal glucose with no additions). $\mathrm{n}=6$; $\dagger=\mathrm{p}<0.05$ and $*=p<0.002$, when compared to the same condition without DMA.

to the mechanisms and physiological implications of such effects. This could be due in part to the lack of accurate methods for monitoring $\mathrm{pH}_{\mathrm{i}}$. Previous methods used for measuring $\mathrm{pH}_{\mathrm{i}}$ include carboxyfluorescein, BCECF, and intracellular microelectrodes. SNARF, a relatively new class of $\mathrm{pH}$ indicators, is more suitable due to efficient loading and retention in the cells, as well as being a ratiometric dye which minimizes variation due to differences in loading or fluctuations of laser intensity. Simple carboxy SNARF-AM esters are particularly suitable for measuring cytosolic pH exclusively, as these compounds, loaded under the current conditions, remain localized in the cytosol. (The more complex carboxy SNARF-calceinAM form, which accumulates in cellular organelles, is better suited for measuring $\mathrm{pH}$ in selected organelles). Carboxy SNARF-AM esters diffuse through the cell membrane and are hydrolyzed by cytosolic esterases, consequently getting trapped in the cytosol with minimal leakage or compartmentalization [52-56]. Recently developed SNARF5 [35], with a pKa of 7.2, is most suitable for monitoring the physiological $\mathrm{pH}_{\mathrm{i}}$ range (compared to SNARF1 (pKa 7.5), SNARF4 (pKa 6.4) or carboxyfluorescein (pKa 6.5)). In our experiments, SNARF5-AM loaded efficiently into the cultured islets, even though the center of most islets remained largely unstained due to the short loading
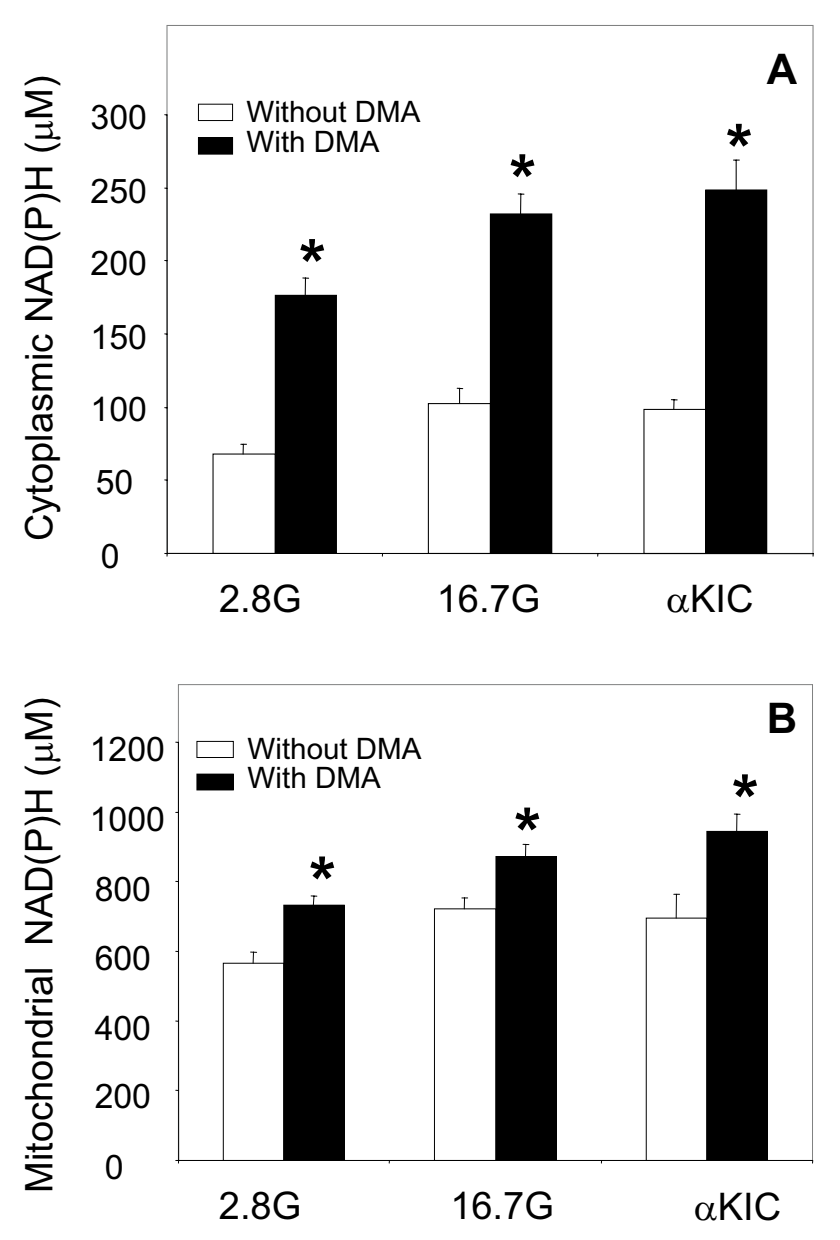

Figure 8

DMA increases cytoplasmic and mitochondrial NAD(P)H production: Islets were placed in basal $\mathrm{KRBH}$ with or without $40 \mu M$ DMA. NAD(P)H auto-fluorescence in cytoplasmic $(A)$ and mitochondrial $(B)$ regions was measured by TPEM before and after addition of $16.7 \mathrm{mM}$ glucose or 20 mM $\alpha$ KIC. A. $n=6$; $*=p<0.001$, compared to same condition without DMA. B. $n=6 ; *=p<0.05$, compared to same condition without DMA.

time. The $\mathrm{pH}_{\mathrm{i}}$-calculations were done using regions-ofinterest chosen from selected well-loaded areas closer to the center of each islet. Since the interior of mouse islets consists almost entirely of $\beta$ cells (other cell types being concentrated on the outside) this technique ensured the $\mathrm{pH}$ measurements being performed in $\beta$ cells. Islets loaded with SNARF5 showed consistent visible changes in emission fluorescence proportional to changes of $\mathrm{pH}_{\mathrm{i}}$ (Fig. 1). 
A remarkable finding in this study was that TDP by glucose, a function normally absent in mouse islets, could be induced simply by lowering the $\mathrm{pH}_{\mathrm{i}}$ with DMA. This indicates that the absence of TDP in mouse islets is not due to lack of the necessary mechanisms, but that these mechanisms are normally inactive, and require the proper $\mathrm{pH}_{\mathrm{i}}$ range for activation. This finding complements the results of previous studies where a TDP-like function was unmasked in mouse islets by activation of PKC $[15,57]$, and where TDP normally present in rat islets was greatly enhanced by lowering $\mathrm{pH}_{\mathrm{i}}$ [12]. Since the induction of TDP has been known to correct the secretory defect in certain diabetic patients $[2,18,19]$, it should be worthwhile to explore the therapeutic value of inducing TDP using $\mathrm{pH}_{\mathrm{i}}$-lowering drugs combined with non-glucose secretagogues.

In addition to unmasking TDP, decrease of $\mathrm{pH}_{\mathrm{i}}$ significantly influenced direct insulin release by mitochondrial fuels. DMA produced a fall of islet $\mathrm{pH}_{\mathrm{i}}$ by $0.2-1.0 \mathrm{pH}$ units, bringing it down from the basal range of 6.9-7.2 to the lower range of 6.4-6.8. All the mitochondrial fuels tested produced strong insulin secretion when the $\mathrm{pH}_{\mathrm{i}}$ was in this lower range, indicating a below-basal $\mathrm{pH}_{\mathrm{i}}$ to be optimal for insulin secretion. MP, which failed to produce insulin secretion, presumably due to its strong acidifying effect, could be made to stimulate insulin release by forcing the $\mathrm{pH}_{\mathrm{i}}$ back to this favorable range (Fig. 5). The magnitude of insulin secretion normally produced by leucine, $\alpha \mathrm{KIC}$ and $\mathrm{BCH}$, compounds that produce no significant change in islet $\mathrm{pH}_{\mathrm{i}}$, was also greatly enhanced by bringing the $\mathrm{pH}_{\mathrm{i}}$ to the lower range with DMA (Fig. 4). Furthermore, NSIS was consistently inhibited by raising the $\mathrm{pH}$ above 7.5. These results demonstrate that nutrients can produce insulin secretion only within a certain range of islet $\mathrm{pH}_{\mathrm{i}}$ whose upper margin is 7.5. The lower margin may possibly fall around 6.3, as indicated by the data with MP. The most favorable $\mathrm{pH}_{\mathrm{i}}$ range for secretion (as well as for unmasking TDP) is near the lower end of this range, between 6.4-6.8, as is the case when MP is combined with a $\mathrm{Cl}^{-}$-free high $\mathrm{pH}$ medium or when other non-acidifying nutrients are combined with DMA. These results are in agreement with many previous studies that showed a decrease of $\mathrm{pH}_{\mathrm{i}}$ being associated with enhanced insulin secretion, $\mathrm{Ca}^{2+}$-influx and electrical activity [23-31]. One early study of particular relevance [32] indicated that a below basal $\mathrm{pH}_{\mathrm{i}}$ is optimal for insulin secretion in rat islets by both glucose and $\alpha \mathrm{KIC}$, but also showed that an increase of extracellular $\mathrm{pH}$ up-to 7.8 can enhance insulin secretion. While the latter result appears to differ from our findings, the previous work did not show simultaneous $\mathrm{pH}_{\mathrm{i}}$ measurements. Since the strong buffering capacity of $\beta$ cells prevents any significant increase of $\mathrm{pH}_{\mathrm{i}}$ until the extracellular $\mathrm{pH}$ is increased above 8 , the reported increase of insulin release likely occurred while the intracellular $\mathrm{pH}$ was still within the normal range.

It is known from this and previous studies that mitochondrial fuels alone can stimulate considerable insulin secretion. The magnitude of such insulin release is less than that of glucose, suggesting that mitochondrial metabolism does not produce the full range of secretory signals generated by glucose. However, our secretion data from compounds such as leucine, $\alpha \mathrm{KIC}$ and $\mathrm{BCH}$ show that mitochondrial activation alone is adequate to produce strong insulin secretion, as long as the $\mathrm{pH}_{\mathrm{i}}$ is maintained in the appropriate lower range. Similarly, when the mitochondrial component of glucose metabolism is eliminated with AOA and CHC (a situation which normally inhibits GSIS), glucose can still produce the full magnitude of insulin release once the $\mathrm{pH}_{\mathrm{i}}$ is decreased with DMA. Hence, an appropriate $\mathrm{pH}_{\mathrm{i}}$ can compensate for those secretory signals that are lacking in each situation, regardless of whether these signals originate in the cytosol or mitochondria. Since carboxy SNARF-AM esters localize in the cytosol with minimal compartmentalization, we expect the current $\mathrm{pH}_{\mathrm{i}}$-measurements to principally reflect the cytosolic $\mathrm{pH}$ and not that of granules or other organelles. It would, however, be very interesting to see how intragranular $\mathrm{pH}$ and intra-mitochondrial $\mathrm{pH}$ affects different components of insulin secretion. Manipulating the loading conditions or using different SNARF-AM derivatives can promote compartmentalization of the dye into organelles, but more sophisticated techniques are necessary to distinguish different organelles from each other.

The mechanisms whereby a low $\mathrm{pH}_{\mathrm{i}}$ enhances or unmasks secretory signals are unclear. Since the depolarizationmediated insulin secretion by high $\mathrm{K}^{+}$was not significantly affected by $\mathrm{pH}_{\mathrm{i}}$-alteration, it is not likely that the distal steps of the secretory pathway are involved. The positive influence of acidification was prominent only on nutrient-derived signals, suggesting enhancement of nutrient metabolism by $\mathrm{H}^{+}$ions, possibly by activating key metabolic enzymes. Some of the $\mathrm{Ca}^{2+}$-activated mitochondrial dehydrogenases such as $\alpha$-ketoglutarate dehydrogenase and isocitrate dehydrogenase are activated by low $\mathrm{pH}$ [58-61]. Glutamate dehydrogenase, a key enzyme in the insulin secretion produced by $\mathrm{BCH}$ and leucine, is also reported to be $\mathrm{pH}$-sensitive [62]. By activating these enzymes, $\mathrm{H}^{+}$ions may enhance TCA cycle metabolism and increase the production of secretory messengers, thus enhancing the secretory capacity of mitochondrial fuels. An indirect but accurate indication as to whether low $\mathrm{pH}_{\mathrm{i}}$ enhances cellular metabolism can be obtained by measuring metabolic products such as NADH and NADPH in the presence of nutrients and acidifying agents. As shown in Fig. 8, DMA significantly increases NAD(P)H production, 
which leads to increased cytoplasmic $\mathrm{NAD}(\mathrm{P}) \mathrm{H}$ even in the absence of stimulatory nutrients. A role for NAD $(\mathrm{P}) \mathrm{H}$ is further evidenced by the fact that DMA reverses the inhibition of GSIS by AOA and CHC (Fig. 6B), and simultaneously raises $\mathrm{NAD}(\mathrm{P}) \mathrm{H}$ (Fig. 7). However, in spite of the rise in $\mathrm{NAD}(\mathrm{P}) \mathrm{H}$, DMA does not produce insulin secretion in the absence of a nutrient secretagogue (Fig. $4 \mathrm{~A})$. Hence, it is possible that this rise represents NADPH alone, which is insufficient to stimulate secretion, but prepares the cellular environment for better secretion by $\mathrm{NADH}$-producing nutrients [39]. DMA-induced low $\mathrm{pH}_{\mathrm{i}}$ may either activate NADPH-producing enzymes with acidic pH-optimum, such as GDH [62], or inhibit NADPH-utilizing enzymes with alkaline pH-optimum, such as nitric oxide synthase [63-66]. As shown in previous studies with pyruvate [39], a rise in NADPH alone is not sufficient to stimulate insulin secretion, but can enhance secretion by NADH-generating nutrients. Thus, a decrease in islet $\mathrm{pH}_{\mathrm{i}}$ activates or "primes" metabolic pathways to generate extra secretory signals so that nutrients can perform their secretory function more efficiently.

The current results show that intracellular $\mathrm{pH}$ determines the ability of nutrients to stimulate insulin secretion. This is not surprising, since most biological functions are sensitive to $\mathrm{pH}$ and have an optimal range of $\mathrm{pH}$. However, it is remarkable that the optimal $\mathrm{pH}$-range for insulin secretion is on the acidic side, and that a relatively small increase of $\mathrm{pH}$ above the physiological range is enough to strongly inhibit NSIS. Therefore, it is possible that a small defect in $\mathrm{pH}_{\mathrm{i}}$ regulation may cause a significant defect in insulin secretion. This is particularly relevant in NIDDM where islet $\mathrm{pH}_{\mathrm{i}}$ can decrease below the normal range due to plasma acidosis, or increase above the normal range either through overcompensation for acidosis or due to hyperglycemia. Such a mis-regulation of $\mathrm{pH}_{\mathrm{i}}$ may well contribute to the secretory defect in NIDDM. Whether or not this is the case, an experimental alteration of $\mathrm{pH}_{\mathrm{i}}$ to bring it to the optimal range should still improve insulin secretion in defective islets, and merits attention as a potential therapeutic approach.

\section{Conclusions}

This study shows that islet $\mathrm{pH}_{\mathrm{i}}$ is a critical factor that determines the presence and magnitude of different aspects of NSIS in mouse islets. The most favorable $\mathrm{pH}_{\mathrm{i}}$ for NSIS is below basal, falling between 6.4 and 6.8. Forcing islet $\mathrm{pH}_{\mathrm{i}}$ to this range a) enables glucose to induce TDP, a function normally absent in mouse islets; b) enhances direct insulin secretion by all mitochondrial secretagogues tested; and c) overcomes the inhibition of GSIS produced by mitochondrial inhibitors. These actions may be mediated through increased nutrient metabolism, as evidenced by the increase of cellular NAD $(\mathrm{P}) \mathrm{H}$ levels associated with lowered $\mathrm{pH}_{\mathrm{i}}$. The favorable effect of below-basal $\mathrm{pH}_{\mathrm{i}}$ on
NSIS, particularly its ability to induce TDP, is of potential therapeutic value for correcting the secretory defect in certain cases of NIDDM.

\section{List of abbreviations}

NSIS: nutrient-stimulated insulin secretion; $\mathrm{pH}_{\mathrm{i}}$ : intracellular pH; TPEM: two-photon excitation microscopy; GSIS: glucose-stimulated insulin secretion; NIDDM: non-insulin dependent diabetes mellitus; $\mathrm{K}_{\mathrm{ATP}}$ channels: ATPdependent $\mathrm{K}^{+}$channels; TDP: Time-dependent potentiation; KRBH: HEPES-buffered Krebs Ringer Bicarbonate solution; DMA: di-methyl amiloride; MP: methyl pyruvate; $\alpha$ KIC: alpha-ketoisocaproate; $\mathrm{BCH}$ : 2-amino-bicyclo[2,2,1]heptane-2-carboxylic acid; GDH: glutamate dehydrogenase; SNARF5: carboxy-seminaphthorhodofluor-5; CHC: $\alpha$-hydroxycyanocinnamic acid; AOA: amino-oxy acetic acid.

\section{Competing interests}

None declared.

\section{Authors' contributions}

SCG designed the study and carried out the insulin secretion experiments and intracellular pH-measurements. JVR performed the $\mathrm{NAD}(\mathrm{P}) \mathrm{H}$ measurements. WSH prepared the cultured islets used in $\mathrm{pH}_{\mathrm{i}}$ and $\mathrm{NAD}(\mathrm{P}) \mathrm{H}$ measurements. DWP participated in the design and coordination of the study. All authors read and approved the final manuscript.

\section{Acknowledgements}

This work was supported by the NIH grants DK42502 and DK53434. Some experiments and data analysis were performed in part through the use of the DRTC Hormone Core Resource and VUMC Cell Imaging Core Resource (supported by NIH grants CA68485, DK20593 and DK58404).

\section{References}

I. Straub SG, Sharp GW: Glucose-stimulated signaling pathways in biphasic insulin secretion. Diabetes Metab Res Rev 2002, 18:45I-463.

2. Nesher R, Cerasi E: Modeling phasic insulin release: immediate and time-dependent effects of glucose. Diabetes 2002, 5 I (Suppl I):S53-S59.

3. Henquin JC, Ishiyama N, Nenquin M, Ravier MA, Jonas JC: Signals and pools underlying biphasic insulin secretion. Diabetes 2002, $5 \mathrm{I}:$ S60-S67.

4. Nesher R, Cerasi E: Biphasic insulin release as the expression of combined inhibitory and potentiating effects of glucose. Endocrinology 1987, 1 21 1:1017-1024.

5. Cerasi E: Potentiation of insulin release by glucose in man. II. Role of the insulin response, and enhancement of stimuli other than glucose. Acta Endocrinologica 1975, 79:502-510.

6. Grill V, Rundfeldt M: Effects of priming with D-glucose on insulin secretion from rat pancreatic islets: Increased responsiveness to other secretagogues. Endocrinology 1979, 1 05:980-987.

7. Gembal M, Gilon P, Henquin JC: Evidence that glucose can control insulin release independently from its action on ATPsensitive $\mathbf{K}^{+}$channels in mouse B cells. J Clin Invest 1992, 89: $1288-1295$.

8. Sato Y, Aizawa T, Komatsu M, Okada N, Yamada T: Dual functional role of membrane depolarization/ $\mathrm{Ca}^{2+}$ influx in rat pancreatic B-cell. Diabetes 1992, 41:438-443. 
9. Taguchi N, Aizawa T, Sato Y, Ishihara F, Hashizume K: Mechanism of glucose-induced biphasic insulin release: physiological role of adenosine triphosphate-sensitive $\mathrm{K}^{+}$channel-independent glucose action. Endocrinology 1995, 136:3942-3948.

10. Komatsu M, Schermerhorn T, Aizawa T, Sharp GWG: Glucose stimulation of insulin release in the absence of extracellular $\mathrm{Ca}^{2+}$ and in the absence of any increase in intracellular $\mathrm{Ca}^{2+}$ in rat pancreatic islets. Proc Natl Acad Sci, USA 1995, 92:10728-10732.

II. Komatsu M, Schermerhorn T, Noda M, Straub SG, Aizawa T, Sharp GWG: Augmentation of insulin release by glucose in the absence of extracellular $\mathrm{Ca}^{2+}$ : New insights into stimulussecretion coupling. Diabetes 1997, 46:1928-1938.

12. Gunawardana SC, Sharp GW: Intracellular $\mathbf{p H}$ plays a critical role in glucose-induced time-dependent potentiation of insulin release in rat islets. Diabetes 2002, $51: 105-113$.

13. Yamada S, Komatsu M, Aizawa T, Sato $Y$, Yajima H, Yada $T$, Hashiguchi S, Yamauchi K, Hashizume K: Time-dependent potentiation of the beta-cell is a $\mathrm{Ca}^{2+}$-independent phenomenon. J Endocrinol 2002, I 72:345-354.

14. Grill V, Adamson U, Cerasi E: Immediate and time-dependent effects of glucose on insulin release from rat pancreatic tissue: Evidence for different mechanisms of action. I Clin Invest 1978, 61:1034-1043.

15. Zawalich WS, Zawalich KC: Species differences in the induction of time-dependent potentiation of insulin secretion. Endocrinology 1996, 137:1664-1669.

16. Berglund O: Lack of glucose-induced priming of insulin release in the perfused mouse pancreas. J Endocrinol | 987, I | 4: | 85- I89.

17. Berglund $O$ : Different dynamics of insulin secretion in the perfused pancreas of mouse and rat. Acta Endocrinol 1980, 93:54-60.

18. Cerasi E: Potentiation of insulin release by glucose in man. III. Normal recognition of glucose as a potentiator in subjects with low insulin response and in mild diabetics. Acto Endocrinologica 1975, 79:5 II-534.

19. Nesher R, Abramovitch E, Cerasi E: Correction of diabetic pattern of insulin release from islets of the spiny mouse (Acomys cahirinus) by glucose priming in vivo. Diabetologia 1985 , 28:233-236.

20. Grill V, Efendic S: Loss of priming effect of glucose on A and D cell secretion in perfused pancreas from alloxan-diabetic rats: role of insulin and alloxan. Diabetologia 1983, 24:47-5I.

21. Grill V, Rundfeldt $M$ : Abnormalities of insulin responses after ambient and previous exposure to glucose in streptozotocindiabetic and dexamethazone-treated rats. Role of hyperglycemia and increased B-cell demands. Diabetes 1986, 35:44-5I.

22. Nadi AB, Malaisse WJ: Altered metabolic priming by D-glucose in pancreatic islets from Goto-Kakizaki rats. Int J Mol Med 2000, 5:625-629.

23. Pace CS: Role of $\mathbf{p H}$ as a transduction device in triggering electrical and secretory responses in islet B cells. Federation Proceedings 1984, 43:2379-2384.

24. Smith JS, Pace CS: Modification of glucose-induced insulin release by alteration of $\mathrm{pH}$. Diabetes 1983, 2:61-66.

25. Pace CS, Tarvin JT, Smith JS: Stimulus-secretion coupling in beta-cells: modulation by pH. Am J Physiol 1983, 244:E3-EI8.

26. Best L, Bone EA, Meats JE, Tomlinson S: Is intracellular $\mathbf{p H}$ a coupling factor in nutrient-stimulated pancreatic islets? J Mol Endocrinol 1988, 1:33-38.

27. Best L, Yates AP, Gordon C, Tomlinson S: Modulation by cytosolic $\mathrm{pH}$ of calcium and rubidium fluxes in rat pancreatic islets. Biochem Pharmacol 1988, 37:46 I I-46I5.

28. Best L, Elliot AC: Changes in 2',7'-bis(carboxyethyl) 5'(6')-carboxyflurescein, fura- 2 and autofluorescence in intact rat pancreatic islets in response to nutrients and non-nutrients. Mo Cell Endocrinol 1995, I II:191-198.

29. Sener A, Hutton JC, Kawazu S, Boschero AC, Somers G, Devis G, Herchuelz A, Malaisse WJ: The stimulus-secretion coupling of glucose-induced insulin release; Metabolic and functional effects of $\mathrm{NH}_{4}{ }^{+}$in rat islets. J Clin Invest 1978, 62:868-878.

30. Lebrun $P$, Van Ganse E, Juvent M, Deleers M, Herchelz A: $\mathbf{N a}^{+}-\mathbf{H}^{+}$ exchange in the process of glucose-induced insulin release from the pancreatic B-cell. Effects of amiloride on 86Rb, 45Ca fluxes and insulin release. Biochim Biophys Acta 1982 , 886:448-456.
3I. Lynch AM, Meats JE, Best L, Tomlinson S: Effects of nutrient and non-nutrient stimuli on cytosolic $\mathrm{pH}$ in cultured insulinoma (HIT-T I 5) cells. Biochim Biophys Acta 1989, I0 I 2:166-170.

32. Hutton JC, Sener A, Herchuelz A, Valverde I, Boschero AC, Malaisse W]: The stimulus-secretion coupling of glucose-induced insulin release. XLII. Effects of extracellular $\mathrm{pH}$ on insulin release: their dependency on nutrient concentration. Horm Metab Res 1980, 1 2:294-299.

33. Lindstrom P, Sehlin J: Effect of intracellular alkalinization on pancreatic islet calcium uptake and insulin secretion. Biochem J 1986, 239: 199-204.

34. Lindstrom P. Sehlin J: Effect of glucose on the intracellular pH of pancreatic islet cells. Biochem J 1984, 21 8:887-892.

35. Liu J, Diwu Z, Leung WY: Synthesis and photophysical properties of new fluorinated benzo(c)xanthene dyes as intracellular pH indicators. Bioorg Med Chem Let 200 I, I I :2903-2905.

36. Sener A, Malaisse WJ: L-leucine and a nonmetabolized analogue activate pancreatic islet glutamate dehydrogenase. Nature (London) 1980, 288: 187-189.

37. Liu Y-J, Cheng H, Drought H, MacDonald MJ, Sharp GWG, Straub SG: Activation of the KATP channel-independent signaling pathway by the non-hydrolysable analog of leucine, BCH. Am J Physiol 2003, 285:E380-E389.

38. Gylfe E: Comparison of the effects of leucines, non-metabolizable leucine analogues and other insulin secretagogues on the activity of glutamate dehydrogenase. Acta diabet Lat 1976, 13:20-24.

39. Rocheleau JV, Head WS, Nicholson WE, Powers AC, Piston DW: Pancreatic islet beta-cells transiently metabolize pyruvate. J Biol Chem 2002, 277:309|4-30920.

40. Lacy PE, Kostianovsky M: Method for the isolation of intact islets of Langerhans from the rat pancreas. Diabetes 1967, 16:35-39.

4I. Arkhammar POG, Terry BR, Kofod H, Thastrup O: Pancreatic islets cultured on extracellular matrix: An excellent preparation for microfluorometry. Methods Cell Sci 1998, 19:255-268.

42. Patterson GH, Knobel SM, Arkhammar P, Thastrup O, Piston DW: Separation of the glucose-stimulated cytoplasmic and mitochondrial NAD(P)H responses in pancreatic islet beta cells. Proc Natl Acad Sci USA 2000, 97:5203-5207.

43. Bennett BD, Jetton TL, Ying G, Magnuson MA, Piston DW: Quantitative subcellular imaging of glucose metabolism within intact pancreatic islets. J Biol Chem 1996, 27 I:3647-365I.

44. Piston DW, Knobel SM: Quantitative imaging of metabolism by two-photon excitation microscopy. Methods Enzymol 1999, 307:35I-368.

45. Zhang Q, Piston DW, Goodman RH: Regulation of corepressor function by nuclear NADH. Science 2002, 295: /895-। 897.

46. Sener A, Kawazu S, Hutton JC, Boschero AC, Devis G, Somers G, Herchuelz A, Malaisse WJ: The stimulus-secretion coupling of glucose-induced insulin release. Effect of exogenous pyruvate on islet function. Biochem J 1978, I76:2 17-232.

47. Lenzen S: Effects of alpha-ketocarboxylic acids and 4-pentenoic acid on insulin secretion from the perfused rat pancreas. Biochem Pharmacol 1978, 27:1321-I324.

48. Leclercq-Meyer V, Garcia-Martinez JA, Villanueva-Penacarrillo ML, Valverde I, Malaisse W]: In vitro and in vivo insulinotropic action of methyl pyruvate. Horm Metab Res 1995, 27:477-48I.

49. Bakkali Nadi A, Zhang TM, Malaisse WJ: Effects of the methyl esters of pyruvate, succinate and glutamate on the secretory response to meglitinide analogues in rat pancreatic islets. Pharmacol Res 1996, 33:191-194.

50. Malaisse WJ, Jijakli H, Ulusoy S, Cook L, Best L, Vinambres C, Villanueva-Penacarrillo ML, Valverde I, Sener A: Insulinotropic action of methyl pyruvate: secretory, cationic, and biosynthetic aspects. Arch Biochem Biophys 1996, 335:229-244.

51. Jijakli H, Nadi AB, Cook L, Best L, Sener A, Malaisse WJ: Insulinotropic action of methyl pyruvate: enzymatic and metabolic aspects. Arch Biochem Biophys 1996, 335:245-257.

52. Muller-Borer BJ, Yang H, Marzouk SAM, Lemasters J], Cascio WE: $\mathrm{pHi}$ and $\mathrm{pHo}$ at different depths in perfused myocardium measured by confocal fluorescence microscopy. Am J Physiol 1998, 275: HI937-HI947.

53. Haugland RP: Molecular Probes Handbook of Fluorescent Probes and Research Chemicals 1992-1994. Molecular Probes, Eugene, OR 51992:129. 
54. Blank PS, Silverman HS, Chung OY, Hogue BA, Stern MD, Hansford RG, Lakatta EG, Capogrossi MC: Cytosolic pH measurements in single cardiac myocytes using carboxy-seminaphthorhodafluor-I. Am J Physiol 1992, 263: $\mathrm{H} 276-\mathrm{H} 284$.

55. Slayman CL, Moussatos VV, Webb WW: Endosomal accumulation of pH indicator dyes delivered as acetoxymethyl esters. J Exp Biol 1994, 196:419-438.

56. Wieder ED, Hang H, Fox MH: Measurement of intracellular pH using flow cytometry with carboxy-SNARF-I. Cytometry 1993, | 4:9|6-92|.

57. Zawalich WS, Zawalich KC, Ganesan S, Calle R, Rasmussen H: Effects of the phorbol ester phorbol I 2-myristate I3-acetate on islet-cell responsiveness. Biochem J 1991, 278:49-56.

58. Denton RM, McCormack JG: The calcium sensitive dehydrogenases of vertebrate mitochondria. Cell Calcium 1986, 7:377-386.

59. Nichols BJ, Rigoulet M, Denton RM: Comparison of the effects of $\mathrm{Ca}^{2+}$, adenine nucleotides and $\mathrm{pH}$ on the kinetic properties of mitochondrial NAD(+)-isocitrate dehydrogenase and oxoglutarate dehydrogenase from the yeast Saccharomyces cerevisiae and rat heart. Biochem J 1994, 303:46I-465.

60. Kim YO, Koh HJ, Kim SH, Jo SH, Huh JW, Jeong KS, Lee IJ, Song BJ, Huh TL: Identification and functional characterization of a novel, tissue-specific NAD(+)-dependent isocitrate dehydrogenase beta subunit isoform. J Biol Chem 1999, 274:36866-36875.

61. Lowry M, Ross D: Activation of oxoglutarate dehydrogenase in the kidney in response to acute acidosis. Biochem J 1980, 190:77I-780.

62. Nissim I: Newer aspects of glutamine/glutamate metabolism: the role of acute pH changes. Am J Physiol 1999, 277:F493-F497.

63. Nakada S, Ishikawa T, Yamamoto Y, Kaneko Y, Nakayama K: Constitutive nitric oxide synthases in rat pancreatic islets: direct imaging of glucose-induced nitric oxide production in betacells. Pflugers Arch 2003, 447:305-3II.

64. Lajoix AD, Reggio H, Chardes T, Peraldi-Roux S, Tribillac F, Roye M, Dietz S, Broca C, Manteghetti M, Ribes G, Wollheim CB, Gross R: A neuronal isoform of nitric oxide synthase expressed in pancreatic beta-cells controls insulin secretion. Diabetes 200I, 50:1311-1323.

65. Yaqoob M, Edelstein CL, Wieder ED, Alkhunaizi AM, Gengaro PE, Nemenoff RA, Schrier RW: Nitric oxide kinetics during hypoxia in proximal tubules: effects of acidosis and glycine. Kidney Int 1996, 49:13|4-1319.

66. Fleming $\mathrm{I}$, Hecker $M$, Busse $\mathrm{R}$ : Intracellular alkalinization induced by bradykinin sustains activation of the constitutive nitric oxide synthase in endothelial cells. Circ Res 1994, 74: $1220-1226$

\section{Pre-publication history}

The pre-publication history for this paper can be accessed here:

http://www.biomedcentral.com/1472-6823/4/1/prepub 